\title{
The Influence of Students' Loans Borrowers' Characteristics on Default Rate in Tanzania
}

\author{
Veronica R. Nyahende ${ }^{1}$ \\ ${ }^{1}$ Accounting School, Dongbei University of Finance and Economics, Dalian, China \\ Correspondence: Veronica R. Nyahende, Accounting School, Dongbei University of Finance and Economics, \\ Dalian, China. Tel: 86-138-8949-0851. E-mail: vericsmuta@yahoo.com; venicerobert1@gmail.com
}

$\begin{array}{lr}\text { Received: June 2, } 2013 & \text { Accepted: June 17, } 2013 \quad \text { Online Published: July 18, } 2013 \\ \text { doi:10.5539/hes.v3n4p26 } & \text { URL: http://dx.doi.org/10.5539/hes.v3n4p26 }\end{array}$

\begin{abstract}
The cost of students' loans defaulting has lead to a serious discussion among participants. Substantial attention has been made on the students' loans and its impact on higher education finances while researches on students' loans defaults have not been taken for more than a decade. Therefore this study examines the influence of students' loans borrowers' characteristics on default rate in Tanzania by taking into consideration the background characteristics termed as pre-college measures, these factors includes age, gender and attitude.

This study was conducted in Dar es salaam region, were by five universities from the region formed the basis of the population and respondents encompasses only students who were loans beneficiaries from these universities/colleges. Data were collected from 150 respondents. Data collected were analyzed using Software Package for Statistical Science (SPSS) and the techniques used for data analysis were regression and correlation.

The study concluded that age, gender and attitude has an influence on the students' loans default rate. The study also recommends that higher education students' loans board (HESLB) should conduct an attitude tests among loans applicants before loans provision by using personal interview and observation by competent psychologists on behavioural science by conducting psychomotor test to understand the attitude among the loans applicants, those with negative attitude should be declared ineligible for students' loans. Age should be given priority by HESLB before loans provision only applicants with the age of 18-24 years should be considered as eligible for students' loans. Strict rules and regulation against males applicants should be instituted by HESLB to ensure their ability and willingness to repay back the loans for instance presence of genuine grantor and adequate collateral security. Students' loans beneficiaries should be educated by HESLB to reduce confusion on repayment process.
\end{abstract}

Keywords: students' loans, borrowers' characteristics, default rate, repayment, age, gender, attitude

\section{Introduction}

Students' loans are loans offered to higher education students to pay off educational related expenses such as tuition fees and research expenses (Jackson, 2002). Students' loans has becoming increasingly important due to inability of the government to sustain parallel increase in levels of funding for students financial aid (Johnstone, 2009). However, tuition fees are going up and grants alone are not sufficient to meet the costs of obtaining higher education (Johnstone, 2006). In this aspect there is an increase in growth of students' loans schemes to support higher education due to the increasing importance of higher education in the $21^{\text {st }}$ century. Higher education enhances status and greater earning power to individuals and to the larger society through economic prosperity, advancement of democracy and social justice (Macmillan, 2006).

According to Baum and O'Malley (2003) students' loans borrowers have different characteristics which affects their propensity to repay back the loans hence accelerating the rate of defaulting. These characteristics are categorised into background characteristics termed as pre-college measures, college experiences and post-college measures (Matt \& Teszler, 2003). According to Herr and Burt (2005) pre-college measures are characteristics attained by the students' borrowers before they enroll themselves in college or university these includes age, gender and attitudes. College experiences includes characteristics attained by students' borrowers after they have enrolled themselves in a college or university, these characteristics includes academic achievement as measured by GPAs, financial support and degree completion. Post-college measures which are the characteristics attained by a students' loans borrower after graduation, these includes characteristics such as highest degree attained, 
income and marital status of a borrower.

The students' loans programmes is meant to provide potential students from poor families the chance to invest in their own future by providing them with financial aid when it is needed and allowing them to repay it after graduation (Marcucci \& Johnstone, 2007). However, the recovery is a challenge to the operation of these programmes though the government is putting seed money in it. The students' loans need to be repayed to create a revolving loan fund to support other needy students (Nyahende, 2013). Students' loans repayment has been affected due to poor loan recovery associated to defaulters loans beneficiaries as affected by their age, gender and attitude they have towards loans repayment.

The plan of this paper is as follows. Section 2 will represent the literature review, the methodology used in the study is provided in section 3, section 4 will represent the findings and discussion, section 5 will cover the conclusion and recommendations and section 6 will represent the limitations and directions for future research.

Students' loans defaults cost the government of Tanzania millions of shillings and threaten the viability of the students' loans programme. To answer the question as to why some students repay their students' loans and others default, this study was designed to investigate the influence the students' loans borrowers' characteristics has on the default rate. The study explored more on the background characteristics of borrowers (the pre-college measures) which students brings with him or her to college or university which an institution has little or no ability to affect, such as age, gender and attitude. These are individual characteristics which are embedded on a person himself/herself and are uncontrollable by the college or university attended hence are important.

According to Baum and O'Malley (2003), attitude refers to the borrowers' positive or negative evaluations towards a variety of things which could affect his or her propensity to default, including loans, debt, and other financial responsibilities.

\subsection{Students'Loans Defaults in Tanzania}

Students' loans started to be implemented as a means of financing higher education in Tanzania in year 2004/2005 which were a results of cost sharing policy existed since the colonial period (United Republic of Tanzania [URT], 2007). During this period parents and students were required to meet partial payments through loans to cover the universities expenses such as tuition fees (URT, 2005). According to (Higher Education Students' Loans Board [HESLB], 2004), HESLB was established to supervise all activities concerning supervision and administration of the process of granting students' loans, repayments and recovery of students' loans issued by the government to students pursuing their higher education since July 1994. (HESLB, 2004) continues to explain that in ensuring repayments of already issued students' loans so as to reduce default rate, every students' loans beneficiary, upon successful or unsuccessful completion of his or her studies are required to repay the loan to the government through the board (HESLB, 2004).

According to HESLB (2009), in order to increase the level of repayments and reduction of defaults rate, among other things HESLB has established a fully-fledged section to deal with loan repayments, 4 debts collectors have been engaged to easy collectability of repayment funds. Campaign has been made to arise the repayment attitudes among loans beneficiaries through various meetings, televisions and radios. However Mkinga (2012) explains that, despite the effort made by HESLB to ensure repayment of already issued students' loans, for example issuance of reminder notes to loans beneficiaries, default rate has been increasing in Tanzania. The number of defaulters in Tanzania as at January 2013 is as shown in Table 1. 
Table 1. Defaulters in Tanzania

\begin{tabular}{llllll}
\hline SN & Region & $\begin{array}{l}\text { Numberof } \\
\text { higher education } \\
\text { universities and } \\
\text { colleges }\end{array}$ & $\begin{array}{l}\text { Numberof } \\
\text { defaulters } \\
1994-2005\end{array}$ & $\begin{array}{l}\text { Numberof } \\
\text { infaulters } \\
2006-2009\end{array}$ & Total \\
in & & & \\
& & & & \\
\hline 1. & Dar es salaam & 21 & 17,237 & 29,322 & 46,559 \\
2. & Morogoro & 3 & 5,433 & 5,747 & 11,180 \\
3. & Arusha & 5 & 1,131 & 1543 & 2,674 \\
4. & Iringa & 4 & - & 2,400 & 2,400 \\
5. & Dodoma & 3 & - & 906 & 906 \\
6. & Mwanza & 2 & 152 & 2,005 & 2,157 \\
7. & Zanzibar & 4 & - & 848 & 848 \\
8. & Kigoma & 1 & - & 15 & 15 \\
9. & Tanga & 1 & - & 331 & 331 \\
10. & Kilimanjaro & 5 & 445 & 996 & 1,441 \\
11. & Mbeya & 2 & - & 433 & 433 \\
12. & Overseas & & & 1,462 & 1,462 \\
& Total & 51 & 24,398 & 46,008 & 70,406 \\
\hline
\end{tabular}

Source: HESLB (2012)

Table 1 indicates that, the number of defaulters has been increasing throughout the period since the implementations of cost sharing policy in year 1994/2005 and in year 2006/2009 respectively. (HESLB, 2004) explains that among other things, HESLB is entrusted to recover all loans taken since July 1994 so as to facilitate disbursement to other needy students. Also it continues to explain that any loan beneficiaries who fail to repay the loans at a stipulated time shall be liable to civil proceedings.

Therefore, the results in Table 1 enables the researcher to believe that the increase in default rate among loanees despite all the efforts made to ensure recovery, is due to difference in age, gender and attitude among the students' loans borrowers because these are individual characteristics which are embedded on borrowers themselves and they are uncontrollable.

\subsection{Research Questions}

(1)Does the students' loans borrowers' age influence students' loans default rate?

(2) Does the students' loans borrowers' gender influence students' loans default rate?

(3)Does the students' loans borrowers' attitude influence students' loans default rate?

\subsection{General Objectives}

The general objective of this study is to examine the influence of students' loans borrowers' characteristics on default rate in Tanzania by taking into consideration the background characteristics associated with pre- college measures.

\subsection{Specific Objectives}

(1)To assess the influence of students' loans borrowers' age on the students' loans default rate.

(2) To examine the influence of students' loans borrowers' gender on the students' loans default rate.

(3)To investigate the influence of students' loans borrowers' attitude on the students' loans default rate.

\section{Literature Review}

\subsection{Human Capital Theory and Students'Loans Default Rate}

As argued by Barr (2009) expenditure on education is treated as an investment according to human capital theory 
and not as a consumer item. According to Snooks (2008) an individual is acquiring this human capital through schooling, post school investment and on job training. Becker (1965) view human capital as directly useful in the production process increases a worker's productivity in all tasks, through possibly differentially in different tasks, organizations and situations. However Ishengoma (2004a) argued that, investigation on the influences of default rate in students' loans is a major focus in Tanzania because of the believe in human capital theory. Decrease in default rate will ensure availability of fund to support higher education through provision of students' loans to the needy students. Snook (2008) continued to argue that, students' loans will enhance an educated population within the country which will contribute to the economic development of the country. Olaniyan and Okemakinde (2008) supported that human capital theory assumes that education is a vital factor for improvement of production capacity of the population.

Strong and well-built human capital is the key to succeed in the global economy Palacio, (2002), this strong human capital is achieved through higher education. According to Chapman (2008) defaulters characteristics affecting repayment is a major source of poor repayment which may results into unavailability of fund to support the students' loans scheme. Carnoy (2006) supported that age, gender and attitudes towards students' loans among loans beneficiaries are among the factors affection the repayments of the issued students' loans fund .According to Olaniyan and Okemakinde (2008) many developing countries are aware that investing on higher education is a principle mechanism for development of human knowledge, thus this justifies the need for investigating on the defaulters characteristics influencing the students' loans default rate in Tanzania so as to find a way to achieve the human capital for the country development.

Fagerlind and Saha (1989) commented that, assumptions of human capital theory result into suggestions that cost of education should be borne by the beneficiaries or the recipient and not solely the state. This justifies the reason why the state and beneficiaries should share the cost of higher education through cost sharing. Mora and Vila (2003) supported that, the government has limited resources given a lot of demands from other public sectors apart from education example health and defense sector. They continued to argue that, beneficiaries should bear this cost though proper repayment which can be achieved through reduction of default rate among loans beneficiaries by taking care of the characteristics associated with defaulting among students' loans beneficiaries.

According to Carnoy (2006) pre-college characteristics associated with students' loans beneficiaries are important influencing factors on repayments hence affecting default rate. However Callender (2003) supported that age, gender and attitude among loan beneficiaries should be controlled for maximum repayment and for support of human capital theory assertation concerning enhancement of equity within the country. He continued to argue that, availability of fund through repayment will enhance attainment of higher education to people from low income group society hence reduce inequality within the country. In this regard Barr and Crawford (2005) stated that, by availability of funds through repayments to support higher education, inequalities can be reduced through increased participation in higher education which results into country's economic growth.

According to Eicher and Chevaillier (2002a) increased repayment by reduction of default rate through controlling the characteristics associated with default rate among loans beneficiaries results into efficiency in provision of students loans hence improvement in human capital investment, improvement of occupation and income, contribution to the productivity of the workers as well as reduction of the social inequalities. However the human capital theory concepts which advocate that improvement in human investment through education will results into improvement in occupation and income has been criticized by Psacharopoulos and Patrinos (2002) who argues that sometimes improvement in education and income depends much on other factors such as number of years in service, which is also true for the case of Tanzania.

Eicher and Chevaillier (2002b) supported that, improvement in human capital through education does not always contribute to the productivity of the workers and the reduction of the social inequalities. This is because workers productivities can be affected by other factors apart from improved education, for example job satisfaction, reward structures, motivations as well as other personal characteristics. They further argued that, improvement in educational investment is assumed to decrease the social inequalities by rising income of people from different backgrounds, this is proved to be not always the case because under certain circumstances rising income may lead to inequalities in income distribution within the society.

Therefore, for economic development of the country, there is a need to develop human capital. Students' loans schemes in many developing countries resulted in high defaults due to non-repayment of the amount of loans given to students. Due to this situation the poor students' loans scheme can lead to deterioration of the economy due to the loss of economic revenues. This call for a need to careful implement the students' loans schemes 
which can recover the loans through repayments efficiently by taking into accounts the borrowers' characteristics affecting students' loans default rate which includes among others the borrowers' age, gender and attitude. Moreover a financially sustainable students' loans scheme is the key factor for improvement in the access to higher education so that the human capital can participate efficiently in the economic progress of the country.

\subsection{The Influence of Students' Loans Borrowers' Characteristics on Default Rate}

According to Harrast (2004) borrowers' characteristics are defined as a distinctive feature or an attribute of the graduate students who used students' loans for attainment of higher education. Many researches have been conducted on background characteristics termed as pre-college measures, these includes research done by (Christman, 2000; Herr \& Burt, 2005; Harrast, 2004; Woo, 2002) they mentioned categorically that the pre-college measures characteristics to include borrowers' age, gender and attitude as the factors influencing the students' loans default rate. According to Barone (2006) pre-college measures refers to characteristics that reflect the students' loans borrowers' experience before college attendance. Kinsler and Pavan (2011) supported that, students brought with them the background characteristics, an institution has a little or no ability to affect them, these characteristics includes age, gender and attitude.

However, according to Chapman and Migali (2006a; 2006) there are other factors affecting default rate apart from poor or non repayments caused by age, gender or attitudes among loans beneficiaries. They further argued that, defaulting among developing countries is caused by poor record keeping and administrative structure as well as lack of qualified personnel. Hossler, Gross, Osman and Hillman (2008) argued that, students' loans borrowers who are defaulters begin the loan process with different background characteristics and with limitations that repayers do not have for example they have negative attitude towards debts and repayment.

\subsubsection{The Influence of Age}

Students' loans borrowers' age has an influence on default rate (Kinsler \& Pavan, 2011). According to Podgursky, Ehlert, Monroe, Watson and Wittstruck (2002) each year the older students' as determined by their age raises the default ratio. However, Woo (2002a) argued that, borrowers' age was insignificant predictor to default. According to Flint (1997), default probabilities are increasing by 3\% each year beyond the age of 21 . According to Herr and Burt (2005), older students are more likely to default than younger students. They continue by arguing that, older students have more financial commitments compared to younger students for example family support, which leads into having less amount available for repayments.

However Kesterman (2006) argued that, age has nothing to do with default rate among students' loans borrowers, instead default rate is affected by academic achievement as measured by GPAs. He further argued that, students with higher GPAs tend to default less than students who attained lower GPAs. However, according to Steiner and Teszler (2003), younger students are more likely to default up to three times than the older students. Although later study done by Steiner and Teszler at the same institution produces different results.

According to Christman and Harrast (2000; 2004), the likelihood of loan default increases as the age of students' borrowers increases even after controlling other factors such as income. Woo (2002b) supported that, as a students' borrowers get older, so do the weakening of ties to parents and family who might give financial support, this situation results into older students being more likely to default than younger students.

Therefore it is hypothesized that borrowers' age has an influence on students' loans default rate because age affect the repayment ability among students' loans borrowers.

\section{$H_{I} \quad$ Students'loans borrowers'age has a direct impact on the students'loans default rate.}

\subsubsection{The Influence of Gender}

According to Podgursky, Ehlert, Monroe, Watson and Wittstruck (2002), females are more likely to defaults less than males. However Lochner and Monge-Naranjo (2008) found that, there is no significant difference between females and males borrowers' in the likelihood of defaulting. Volkwein and Szelest (1995) also supported that, there is no significant difference in default rates between males and females.

Hofstede and Michael (2010) contented that, male borrowers default more than women according to masculinity behavior as supported by cultural theory. They further argued that, according to cultural theory the distribution of emotional roles between males and females are different, males are competitive, assertation, materialist, ambitious, power oriented and they don't put value on relationships as well as quality of life. They concluded that, it become easy for them to default from paying back the loan given. Choy and Li (2006) concluded that, women take longer to repay loans as they are assumed to have low income compared to men. According to Kesterman (2003) students who successful complete their studies tend not to default on students loans given 
compared to drop outs regardless of their gender.

According to Hsu (2008) highest degree attained by either a male borrower or a female borrower has an influence on default rate, that is student borrowers who attained certificate level or who have no degree have a high rate of defaulting compared to students' borrowers who have graduated.In the study done in California Woo (2002a) found that borrowers' chance of defaulting is decreasing by $36 \%$ by being a female. Likewise, Flint (1997) in the national study done at Missouri supported that, default probability is increasing by $5.8 \%$ by being a male.

Most of the literatures indicate that, gender among the students' loans borrowers' has a significant influence on the repayment of already issued students' loans, hence can result into an increase or a decrease in default rate. Therefore it is hypothesized that being a female or male among students' loans beneficiaries has an influence on the default rate.

\section{$\mathrm{H}_{2} \quad$ Students' loans borrowers'gender has a direct effect on the students'loans default rate.}

\subsubsection{The Influence of Attitude}

According to Kinsler and Pavan (2011) attitude among loans beneficiaries is defined as a tendency of loans beneficiaries to respond positively or negatively towards loans repayment, they further argued that, an attitude influences a loan beneficiaries individual choices towards repayments hence influences the default rate. Steiner and Teszler (2003) argued that, students borrowers' attitude toward debt, default and dissatisfaction with the institution are the reasons for their default behaviour.

Moreover Baum and O'Malley (2003) concluded that, students' attitudes were related to default rate. They continued to support that differences in attitudes towards debts have an influence on students' loans default rates. However Mower (2007) contented that apart from attitude, financial support from, for example families affect more the students' loans default rate as students with financial support are less defaulters than those with no financial support from their families. Likewise McMillion (2004) supported that, income and marital status of a borrower affects default rate, he further argued that, students' borrowers who are married and have a small number of dependants are more repayers than students' borrowers who are single and have a big number of dependants.

Christman and Monteverde (2000; 2000) supported that, default is primarily influenced by the borrowers' willingness and ability to repay termed as attitude, not to anything the institution is doing. According to Hossler, Gross, Osman and Hillman (2008) defaulters are associated with different perceptions about borrowing, debts and credit, their perception enhance and contribute to default rate.

According to the literature reviewed it has been hypothesized that attitude among students' loans borrowers has an influence of on students' loans default rate.

\section{$H_{3}$ Students'loans borrowers' attitude has a direct impact on the students'loans default rate}

\subsection{Theoretical Justification of Students' Loans}

According to Woodhall (2002a) theoretical justification for students' loans is that higher education is a profitable investment, assuring high returns to graduate in term of better job opportunities and high quality of life which offers higher lifetime earnings. However Woodhall (2007) contented that, students' loans allow potential students from poor families to access higher education regardless of their economic difficulties. She further argued that, these poor students can invest in their own future by being given financial aids through students' loans thereafter they will be required to repay the loans back after graduation. According to Woodhall (2002b) the rationale towards students' loans were summarized by the first student loan program in Latin America which gives the slogan that: "We lend to the student and the professional pays us back".

World Bank (2008a) argued that, the introduction of cost sharing in the form of students loan schemes help in creating a revolving fund, through which more students will be able to access higher education. But this will be possible if default rate will be kept at minimum or is eliminated completely by taking into account the age, gender and attitudes among loans beneficiaries which affect repayment hence affecting the default rates. According to Woodhall (2002b) student loans can help to reduce drop-outs due to availability of funds to support students and also students are free and encouraged to choose careers in the lights of labour market requirements within the economy as they have the confident of completion of their studies.

World Bank (2008b) contented that, the rationale of students' loans was based on both efficiency and equity arguments. According to World Bank (2008a) efficiency arguments for loans relies on the explanations that (a)students' loans relieve the government from fully financing higher education therefore it reduce extremely 
demands on government budget and on tax payers, (b) students' loans provides an alternative sources of finances to higher education therefore it enhances the expansion of higher education to widen access and (c) increasing of students' awareness of the costs of higher education and understandability of their obligation to repay their loans as they will be motivated to evaluate both costs and benefits obtained from higher education attained.

According to World Bank (2008b) equity arguments concentrates on costs and benefits. It is also concluded that, university graduates are expecting higher lifetime income after their education, those whose benefits should not be subsidized by tax payers with average or below average earnings. This arguments resulted into the formation of the basis of the World Banks's three conclusions:(a)"Too great share of public resources goes to higher levels of education, relative to lower" (World Bank, 1986) (b) "Since higher education systems are financed by the entire population but available only to a small minority, they have a regressive fiscal impact" (World Bank, 1994) (c) Cost sharing can be implemented properly with the functioning student loan program so that funds will be available for all students who need to borrow for their education (World Bank, 1994).

Word Bank continued to argue that, students' attending higher education in every developing country represents only an elite group with an income potential significantly higher than of their peer. According to World Bank (2009) the equity argument supported on the use of government guaranteed students loans rather than grants for students' financial support. Therefore improving the efficiency on the functioning of the existing student loans programs by ensuring the availability of fund to be lent to other needy students are the major challenges for developing country governments which is also true in Tanzania. The students' loans scheme or programme should ensure minimization of default rate if not elimination by taking into account the factors influencing default rates among the loans beneficiaries which include age, gender and attitudes.

\subsection{Conceptual Framework}

This paper intends to investigate the influence of students' loans borrowers' age, gender and attitude has on default rate. From various literatures reviewed it was found that all the factors investigated have an influence on the students' loans default rate. As discussed in the literatures reviewed above and cemented by theories, the conceptual framework in Figure 1. has been developed to present the relationship between the students' loans default rate and students' loans borrowers' age, gender and attitudes.

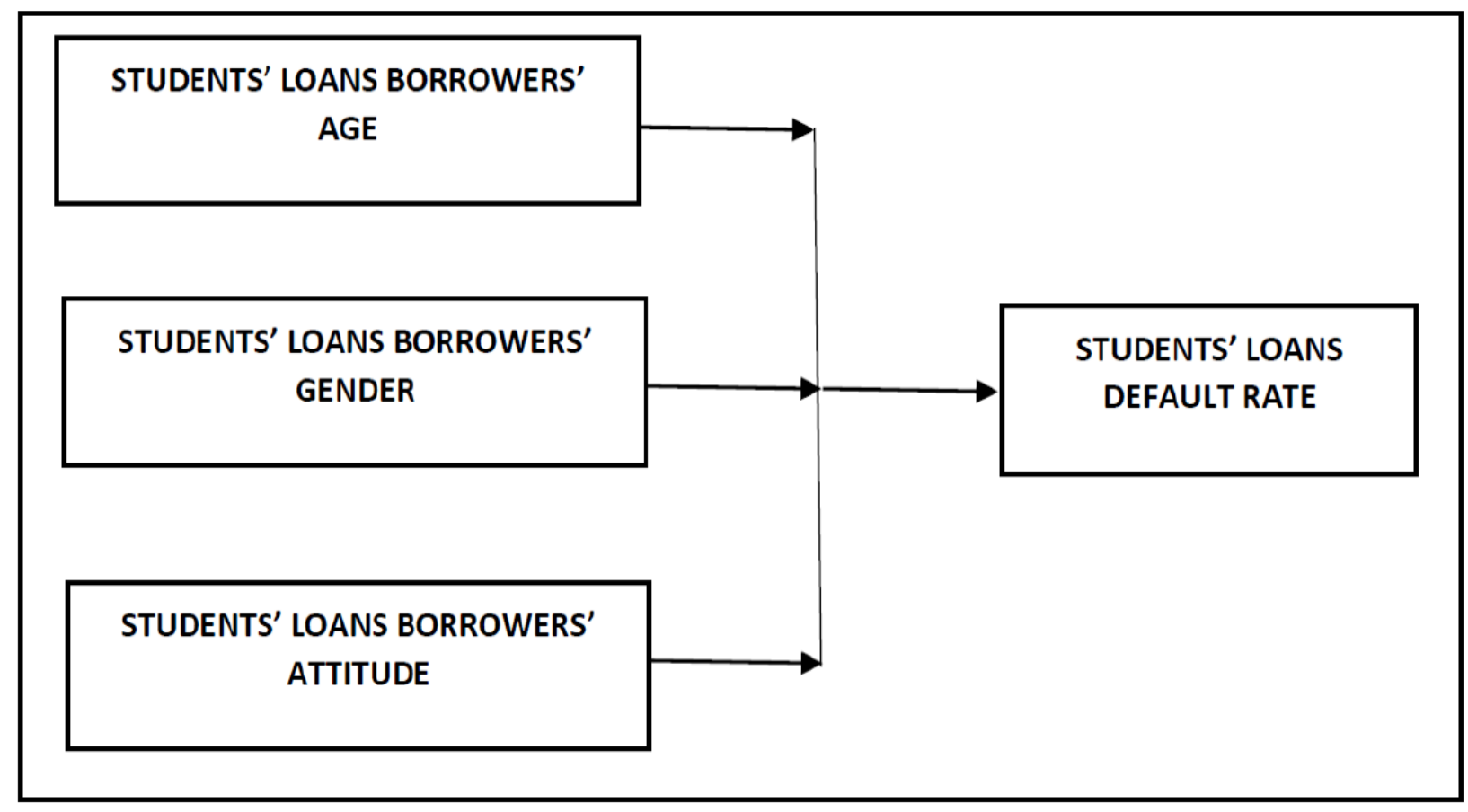

Figure 1. Conceptual framework (1) of the study

Figure 1. Leads to a conclusion that reduction of students' loans default rate in Tanzania depends on overcoming the challenges the students' loans borrowers' age, gender and attitude brought about which affect the repayment 
of the already issued students' loans.

\subsubsection{Age}

Age among students' loans beneficiaries in this study has been categorized into five age groups ranging from 18-24 years, 25-30 years, 31-35 years, 36-40 years and 41 and above years. Categorization among the age group was of vital important as students' loans borrowers do respond differently on repayment depending on their age group. For examples it was expected that due to different age group among students' loans beneficiaries there will be different responses on the willingness to repay loans after completion, whether they have started to repay loans, whether they know that loans is meant to be revolving and whether they follow procedures to repay back the students' loans.

\subsubsection{Gender}

Gender among students' loans beneficiaries in this study has been studied whereby investigation were made regarding gender this is because students' loans borrowers were expected to respond differently on repayment depending on gender. Being a female or a male for examples it was expected that there will be different response on the willingness to repay loans after completion, whether they have started to repay the loans, whether they know that loans is meant to be revolving and whether they follow procedures to repay back the students' loans.

\subsubsection{Attitude}

Attitude among students' loans beneficiaries in this study has been categorized into five ranking ranging from fair, average, good, very good and excellent. Categorization depending on the level of attitude was vital important as students' loans borrowers do respond differently on repayment depending on the attitude they have towards repayment. For examples it was expected that due to different attitude among students' loans beneficiaries there will be different responses on the declaration of debts, whether the borrowers pay debts timely, whether they find the need to maintain good credit history and whether they follow procedures to repay back the students' loans. Figure 2. Explains the conceptual framework (2) incorporating all the items under each independent variable.

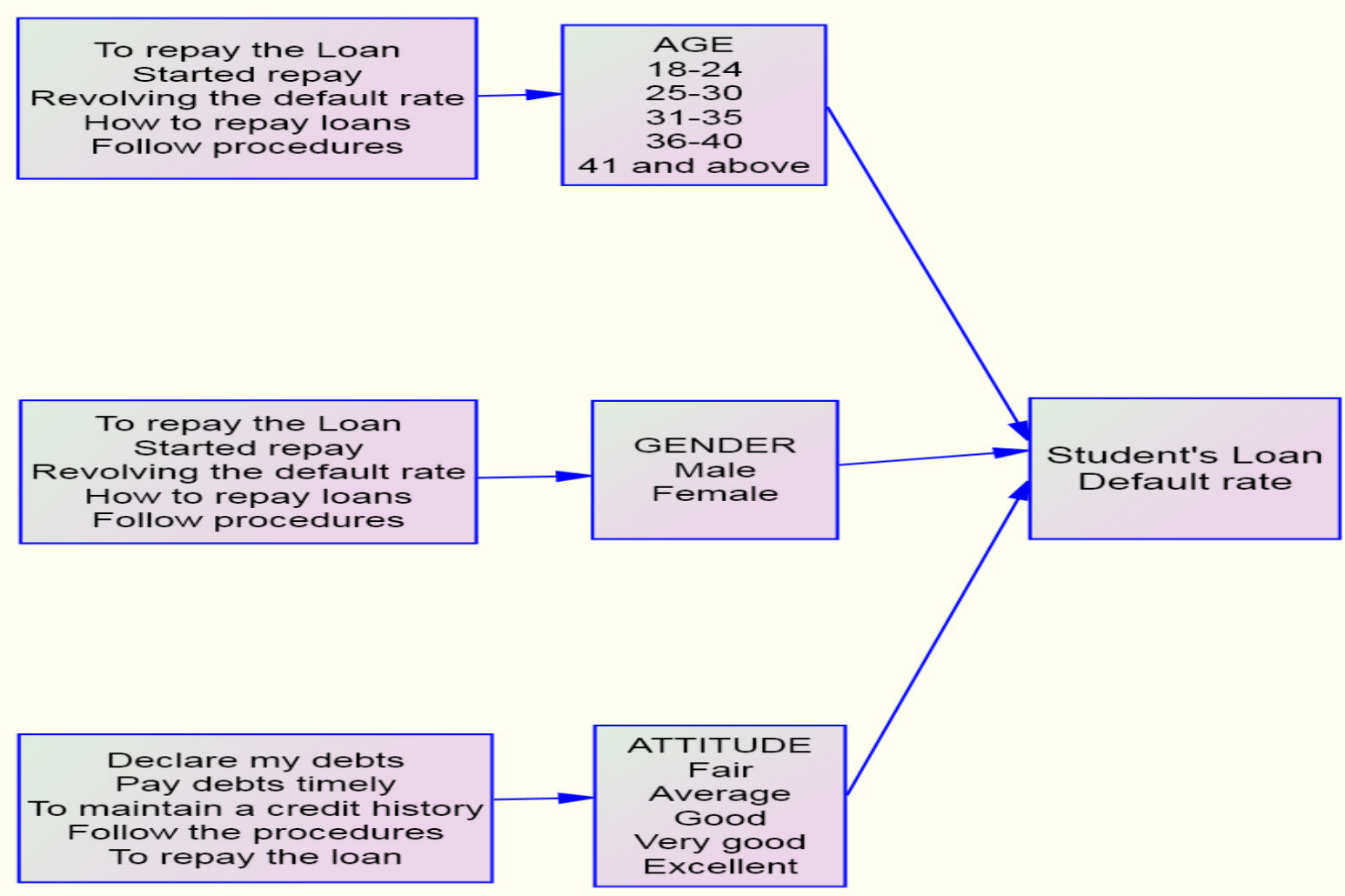

Figure 2. Conceptual framework (2) of this study 


\subsubsection{Students' Loans Default Rate}

Students' loans default rate is a dependent variable, in this study default rate is expected to be influenced by age, gender and attitude among students' loans borrowers which are independent variables. Default rate is being measured in totality from the students' loans scheme itself which is operating under the supervision of higher education students' loans board (HESLB) in Tanzania.

\subsection{Research Hypotheses}

Based on the conceptual framework and literatures reviewed, the researcher constructed three hypotheses that were derived from the three specific objectives. Each hypothesis would provide empirical evidence on the degree of influence on the students' loans default rate brought about by the students' loans borrowers' age, gender and attitude.

Therefore the following hypotheses were developed and tested:

$\mathrm{H}_{1} \quad$ Students' loans borrowers' age has a direct impact on the students' loans default rate.

$\mathrm{H}_{2} \quad$ Students' loans borrowers' gender has a direct effect on the students' loans default rate.

$\mathrm{H}_{3}$ Students' loans borrowers' attitude has a direct impact on the students' loans default rate.

The hypotheses were tested by regression analysis using SPSS programme. These hypotheses were aiming at finding out the causal relationship between (1) age of students' loans borrowers and the students' loans default rate (2) gender of students' loans borrowers and the students' loans default rate and (3) attitude of students' loans borrowers and students' loans default rate.

\section{Methodology}

\subsection{Research Design}

According to Saunders, Lewis and Thornhill (2007) research design is a framework used as a guide in collecting and analyzing data. In this study a descriptive cross sectional research design was used. The research was guided by hypotheses and structured questionnaires were used to collect data where by 5- likert- scale type of questions were administered. Despite of it being expensive way and time consuming the researcher used the personally administered method of data collection due to high respond rate associated with it.

\subsection{The Population, Sample Size and Sampling Procedures}

\subsubsection{Population and Sample Size}

Students' loans beneficiaries from University of Dar es salaam (UDSM), Dar es salaam University College of Education (DUCE), Tumaini University Dar es salaam College (TUDARCO), Institute of Finance Management (IFM) and College of Business Education (CBE) formed the population of this study. Most of these universities or college chosen were the government universities or colleges which were the targeted beneficiaries of students' loans scheme. However, currently even private universities or colleges example TUDARCO in our study benefits from students' loans as well. It was also convenient for the researcher to move around the region as all the universities or colleges in our population were situated in Dar es salaam region in Tanzania.

A sample of 200 respondents were considered in the study after a researcher studied a list of students' loans beneficiaries obtained from the students' loans finances offices from each university within the population. The researcher conveniently decided to use a sample of 200 after satisfying herself with the availability of the students from every university under study. Questionnaires were distributed to 200 students to form a sample of 200 respondents.

\subsubsection{Sampling Procedures}

List of loan beneficiaries students were obtained from the students' loans finances offices from each university. The researcher timed these students when they signed off their meals allowances at the students' finances office which is always done quarterly as per HESLB requirements.

Sampling procedures used were cluster sampling and purposive sampling, where by a cluster of five universities the UDSM, DUCE, TUDARCO, IFM and CBE were randomly chosen to form a group of five clusters in which students' loans beneficiaries were chosen from each cluster obtained. In deciding the participants to be included in the sample, the researcher employed the purposive sampling techniques instead of other sampling techniques because given prior information the researcher has, she believed that selected sample could provide the data needed for the study for example in this study the researcher needed participants who are beneficiaries of students' loans as the means of financing their education so that they will have the knowledge as to how the default rate is 
being affected among them as influenced by age, gender and attitude.

\subsection{Data Collection}

Quantitative data from both primary and secondary data were obtained by this study. (1) Using primary data the researcher obtained information on how the students' loans beneficiaries respond to repaying back their loans to reduce default rate as affected by their age, gender and attitudes. For example the researcher got to understand whether the respondents were willing to repay the loans after completion of their studies and whether they have started to repay back the loans as affected by their age, gender and attitude. The researcher obtained information on whether students' loans beneficiaries have the knowledge that students' loans is meant to be revolving so that much emphasis should be put on repayments. Information on the perception of loans beneficiaries on the whole aspect of the need to maintain good credit history as well as their preference in repaying back their debts were also obtained from primary source.

(2) From secondary data the researcher obtained information concerning strategies used by HESLB to improve repayment and reduction of default rate among loans beneficiaries. A list of defaulters since 1994 to 2009 were obtained from HESLB which also make contribution in this study. Review of students' application forms to explore on the students' loans applicants age wise and gender wise. Review of policies and procedural documents concerning loans provisions and repayments to see whether the procedures are being followed, and also to see whether the students' loans are meant to be segregative age wise, gender wise and whether the attitude test has been insisted to be conducted before loans are given out to test on the willingness and ability of the students' loans applicants to repay back the loans given. A list of students' loans beneficiaries were also obtained from the students' loans finances offices from each university selected this was used as a guide towards sample selection.

\subsection{Data Analysis}

Data collected were analyzed using Software Package for Statistical Science (SPSS) and the analysis techniques employed were the regression and correlation. Regression analysis is said to be the most widely applied data analysis technique for measuring linear relations between two or more variable, (Saunders, Lewis \& Thornhill, 2007). Thus the general multiple linear regression model will be given by:

$$
Y=\beta_{0}+\sum_{j=1}^{n} \beta_{1} x_{1}+\sum_{j=1}^{n} \beta_{2} x_{2}+\sum_{j=1}^{n} \beta_{3} x_{3}+\varepsilon_{i}
$$

Where

$Y$ Represents a the dependent variable which is the students' loans default rate in Tanzania

$\beta_{0}$ Represents a constant factor

$\sum_{j=1}^{n} \beta_{1} x_{1}$ Represents an independent variable, the borrowers age $(A)$

$\sum_{j=1}^{n} \beta_{2} x_{2}$ Represents an independent variable, the borrowers gender $(B)$

$\sum_{j=1}^{n} \beta_{3} x_{3}$ Represents an independent variable, the borrowers attitude $(C)$

$\varepsilon_{i} \quad$ Represents an error term

Assumptions for linear regression model which includes linearity, normality, homoscedasticity and independence were considered after being verified, (David, 2009). 


\section{Findings and Discussion}

The aim of this study was to examine the students' loans borrowers' characteristics influencing default rate. The study explored on the background characteristics such as age, gender and attitude among loans beneficiaries. For achievement of pertinent answers to the questions the study was guided by the following hypotheses:

$\mathrm{H}_{1} \quad$ Students' loans borrowers' age has a direct impact on the students' loans default rate.

$\mathrm{H}_{2}$ Students' loans borrowers' gender has a direct effect on the students' loans default rate.

$\mathrm{H}_{3} \quad$ Students' loans borrowers' attitude has a direct impact on the students' loans default rate.

During data collection the researcher distributed questionnaires to 200 respondents where by only 150 respondents returned completely filled questionnaires making approximately a respond rate of $75 \%$ this indicates a good response in this study. Therefore the study considered a sample of 150 students' loans beneficiaries.

\subsection{Sample Characteristics and Reliability Test}

\subsubsection{Sample Characteristics}

The findings indicates the following sample characteristics (1) more than a half of the respondents were of the age of 18-24 years, the remaining less than a half were distributed among 25-30 years, 31-35 years and 36-40 years, in which respondents with 41 and above years were formed by only $3 \%$ of the respondents. This results were expected by the researcher because the age of 18-24 is a schooling age so more respondents were expected to be of the age between 18-24 years and less on 41 years and above, Refer Table 6 in Appendix II (2) respondents' gender were also fairly represented by the sample because nearly three quarter of the respondents were males where by females forms only a quarter of the respondents. The population was fairly represented as more males than females were expected to be found in higher education studies in developing countries and Tanzania in particular, due to customs and taboos which hinder females from attaining higher education example early marriages, refer Table 7 in Appendix II (3) distribution of respondents by universities or colleges indicates that one third of the respondents were from UDSM, followed by $1 / 5$ of respondents from IFM. The remaining percentages were evenly distributed among DUCE, CBE and TUDARCO. This distributions present a fairly representation because UDSM was expected to have more students loans beneficiaries followed by IFM due to their long term establishment, and they are the public universities which were the reasons for establishment of students' loans scheme in Tanzania. It was assumed that public universities attracts more needy students who qualifies for higher education but unable to finance their education, unlike TUDARCO which rank the last as it is a private university with few students who are loans beneficiaries, refer Table 8 in Appendix II.

\subsubsection{Reliability Test}

In order for the researcher to be able to draw satisfactory conclusions, four reliability tests were conducted for age, gender, attitude and students' loans defaults as shown in Table 9 in Appendix II. According to Cronbach and Richard (2004) normally a good reliability ranges from 0.7 and above, the researcher used the Cronbach test model to test internal consistency of data based on average inter-item correlation. The results of reliability test of the constructs in this study as presented in Table 9 in Appendix II indicates that reliability analysis gave alpha coefficients exceeding 0.7 which are excellent reliability coefficients. The greater the value of the coefficient the more reliable is the construct, therefore age factor in this study is more reliable, followed by attitude factor then the last is the gender factor, refer Table 9 in Appendix II.

\subsection{Hypotheses Testing}

This study has three hypotheses developed from literatures reviewed also it has three constructs which are age, gender and attitude, the data collected were used to test empirically the hypotheses. To test hypotheses correlation analysis were conducted to measure the strength and directions of the association between the independent variables. The results in Table 2 . indicates that the predictor variables were positively related and significantly correlated. 
Table 2. Correlations

\begin{tabular}{lllll}
\hline & & AVRA & AVRB & AVRC \\
\hline \multirow{3}{*}{ AVRA } & Pearson Correlation & 1.000 & $.214^{* *}$ & $.062^{* *}$ \\
& Sig. (2-tailed) & & .000 & .000 \\
& $\mathrm{~N}$ & 150 & 150 & 150 \\
& Pearson Correlation & $.214^{* *}$ & 1.000 & $.009^{* *}$ \\
AVRB & Sig. (2-tailed) & .000 & & .000 \\
& $\mathrm{~N}$ & 150 & 150 & 150 \\
& Pearson Correlation & $.062^{* *}$ & $.009^{* *}$ & 1.000 \\
AVRC & Sig. (2-tailed) & .000 & .000 & \\
& $\mathrm{~N}$ & 150 & 150 & 150 \\
\hline
\end{tabular}

**. Correlation is significant at the 0.01 level (2-tailed).

Source: Field data (2012)

Where:

AVRA Average of items under the age construct

AVRB Average of items under the gender construct

AVRC Average of items under the attitude construct

Further analysis were conducted using multiple regression techniques to analyze the strength of relationship between age, gender, attitudes and the students' loans default rate. The results in Table 3 indicates that, the independent variables accounted for about $89.7 \%$ of the variance on the students' loans default rate. The remaining $10.3 \%$ is explained by other variables not explained by the model. Therefore there is a strong relationship between independent variable and dependent variable $\left(\mathrm{R}^{2}>0.5\right)$. Durbin-Watson value of 1.921 shown in Table 3 indicates the strong relationship between age, gender, attitude and students' loans default rate. The result shows that, there is statistical evidence that the error terms are not positively correlated, the acceptable range for Durbin-Watson is between 1.5-2.00 (Durbin \& Watson, 1951).

Table 3. Model summary

\begin{tabular}{llllll}
\hline Model & $\mathrm{R}$ & R Square & Adjusted R Square & Std. Error of the Estimate & Durbin-Watson \\
\hline 1 & 0.947 & 0.897 & 0.894 & 1.1312 & 1.921 \\
\hline
\end{tabular}

Source: Field data (2012)

The researcher conducted the ANOVA tests too, the results in Table 4 indicates that the model results were statistically significant because the $p$ value is less than 0.05 i.e. $p<0.05$ and its test statistic the $F$ value lying in a location that supported the positive impact. The significant value results into 0.000 hence the value is less than 0.05.Therefore there is a significant relationship between age, gender, attitude and the students' loans default rate hence much variation in dependent variable has been explained by independent variables.

Table 4. ANOVA results

\begin{tabular}{lllllll}
\hline Model & & Sum of Squares & df & Mean Square & F & Sig. \\
\hline \multirow{2}{*}{1} & Regression & 2177.426 & 5 & 435.485 & 1.782 & $.000^{\mathrm{c}}$ \\
& Residual & 249.574 & 145 & 1.721 & & \\
& Total & $2427.000^{\mathrm{d}}$ & 150 & & & \\
\hline
\end{tabular}

Source: Field data (2012)

a. Predictors: (Constant), AVRA, AVRB, AVRC.

b. Dependent variable: AVR 


\subsubsection{Testing of Hypothesis 1}

\section{$H_{I} \quad$ Students'loans borrowers'age has a direct impact on the students'loans default rate.}

This study attempted to test if there were any relationship between age, gender attitude and students' loans default rate. The test was based on students who are loans beneficiaries from UDSM, DUCE, IFM, CBE and TUDARCO. Table 5 indicates that, the regression coefficient $(\beta)$ for students' loans borrowers age (AVRA) is 0.191 which implies that for every unit change in the borrowers age there is 0.191 times change in the degree of students' loans default rate in the same direction (increase or decrease) and $\mathrm{p}=0.000$ : $\mathrm{p}<0.05$, as long as $\mathrm{p}$ value is less than 0.05 , the null hypothesis can be rejected and therefore $\mathrm{H}_{1}$ stands.

Therefore it was concluded that there was $95 \%$ confidence level that the students' borrowers age and the students' loans default rate were positively related, hence the hypothesis 1 is confirmed to be true, students' loans borrowers' age has a direct impact on the students' loans default rate.

Table 5. Coefficients

\begin{tabular}{lcccccccc}
\hline & \multicolumn{3}{c}{$\begin{array}{l}\text { Unstandardized } \\
\text { Coefficients }\end{array}$} & \multicolumn{3}{c}{$\begin{array}{l}\text { Standardized } \\
\text { Coefficients }\end{array}$} & \multicolumn{3}{c}{$\begin{array}{c}\text { Collinearity } \\
\text { statistics }\end{array}$} \\
\hline 1 & $\beta$ & Std. Error & $\beta$ & $\mathrm{t}$ & Sign. & Tolerance & VIF \\
\hline Constant & .014 & .093 & & .352 & .964 & & \\
& AVRA & 0.392 & .083 & .191 & 4.277 & .000 & .005 & 13.57 \\
& AVRB & 0.311 & .076 & .165 & 3.036 & .000 & .004 & 8.785 \\
& AVRC & 0.414 & .097 & .331 & 5.454 & .000 & .224 & 14.92 \\
\hline
\end{tabular}

a. Dependent variable: AVR

Source: Field data (2012)

\subsubsection{Testing of Hypothesis 2}

$\mathrm{H}_{2}$ Students'loans borrowers'gender has a direct effect on the students'loans default rate.

Table 5 indicates the regression coefficient ( $\beta$ ) for students' loans borrowers gender (AVRB) is 0.165 which implies that for every unit change in the borrowers gender there is 0.165 times change in the degree of students' loans default rate in the same direction (increase or decrease) and $\mathrm{p}=0.000$ : $\mathrm{p}<0.05$, as long as $\mathrm{p}$ value is less than 0.05 , the null hypothesis can be rejected and therefore $\mathrm{H}_{2}$ stands.

Therefore it was concluded that there was $95 \%$ confidence level that the students' borrowers gender and the students' loans default rate were positively related, hence the hypothesis 2 is confirmed to be true, students' loans borrowers' gender has a direct effect on the students' loans default rate.

\subsubsection{Testing of Hypothesis 3}

$H_{3}$ Students'loans borrowers'attitude has a direct impact on the students' loans default rate.

Table 5 indicates the regression coefficient $(\beta$ ) for students' loans borrowers attitude (AVRC) is 0.331 which implies that for every unit change in the borrowers attitude there is 0.331 times change in the degree of students' loans default rate in the same direction (increase or decrease) and $\mathrm{p}=0.000$ : $\mathrm{p}<0.05$, as long as $\mathrm{p}$ value is less than 0.05 , the null hypothesis can be rejected and therefore $\mathrm{H}_{3}$ stands.

Therefore it was concluded that there was $95 \%$ confidence level that the students' borrowers attitudes and the students' loans default rate were positively related, hence the hypothesis 3 is confirmed to be true, Students' loans borrowers' attitude has a direct impact on the students' loans default rate.

\section{Conclusions and Recommendations}

\subsection{Conclusions}

Repayment of the already issued students' loans is of vital important to benefit future needy students and to ensure the financial sustainability of the students' loans scheme. In this study the research on borrowers characteristics influencing repayments hence affecting the default rate of students' loans were conducted, where by characteristics of students' borrowers as they begin the college were examined, these characteristics includes age, gender and 
attitudes.

The findings reveal that age has an influence on students loans default rate, as it has been supported by many literatures, the analysis results indicates that the older the borrowers the more the chance of defaulting as the borrower will have greater financial obligation such as family to support that may compete with loan repayment while younger students have relatively fewer financial commitments. Also as students' borrowers get older, so do the weakening of ties to parents and family who might give financial support to them hence it increases the default rate among the older students' borrowers compared to the younger ones. In this study age among students' loans borrowers were categorised into groups of 18-24 years, 25-30 years, 31-35 years, 36-40 years and 41 and above years.

Furthermore study findings reveal that there is an association between gender and the students' loans default rate, that is as supported by some literatures, the chance of defaulting among students' loans decreases by being a female than being a male due to emotional role distribution among female and males as explained by cultural theory. The theory contents that males are more materialist, competitive and they are power oriented they put less value on relationships and quality of life, so defaulting becomes easy for them as they find no need of maintaining good credit history to improve the quality of life.

Lastly the findings revealed a significant relationship between attitudes among students' loans borrowers and default rates. Attitude which was defined by Kinsler and Pavan (2011) as the tendency of loans beneficiaries to respond positively or negatively towards loans repayment, it affects the individual choices towards repayments hence affecting default rate. Attitude in this study has been measured after being categorised as fair, average, good, very good and excellent. The study indicates that an individual students' loans borrowers with a positive attitude towards repayments measured as excellent, default less than students' borrowers with a negative attitude towards repayments measured as fair in this study.

Therefore, the findings indicates that, all the three factors have a significant influences on students' loans default rate though at different magnitude. Whereby attitudes rank the first in contributions towards students' loans default rate, age rank the second in contribution and the last is gender which contribute less to the default rate among students' loans borrowers. Less contribution by gender to default rate has been also supported by different researchers who argue that there is insignificant difference in default rates between males and females, examples the study done by Lochner and Monge-Naranjo (2008).

\subsection{Recommendations}

Though the study revealed that age, gender and attitudes of the students' loans beneficiaries influence their defaults ability, loans beneficiaries need to be educated on the repayment process as they might be defaulting due to presence of confused and bureaucratic procedures on repayment process. Also they need to be educated to realize that the students' loans given has to be repaid to reduce the chances of defaulting.

In analyzing the factors influencing the default rate in Tanzania, this study provide an understanding of the different between the loan defaulters and non-defaulters in order to contribute to informed policymaking on higher education financing on appropriate measures to be taken to reduce, if not eliminating default rate among loans beneficiaries. For example the attitude among the students' loans borrowers needs to be controlled at a very initial stage before loan provision through attitude test, personal interview and observation by competent psychologists on behavioural science. Students who are found to be likely to default should be declared as ineligible for students' loans.

The higher education students' loans board (HESLB) should overcome the challenges brought about by age and gender on default rate by taking some measures before provision of students' loans, for example (1) age should be given priority before loans provision that is only loan applicants with the age of 18-24 years should be considered for first application on students' loans, other age groups should be declared as ineligible for students loans, when students' loans is given to students' at this age group the likely hood is that they will graduate when they are still young, therefore reduction of default rate as it was concluded that default is less among the younger students' borrowers compared to the older ones (2) even though males were formally favoured by the societies in developing countries especially in Tanzania to attain higher education compared to females, HESLB should make sure that males applicants are given less priority to students' loans compared to females through institution of strict rules and regulation to ensure that male applicants are checked on their ability and willingness to repay back the loan. For example they must be required to be guaranteed with a financially stable and genuine guarantor with ability to repay back in case male borrowers fail to repay back the loan, also attitude test should be conducted among males students' loans applicants. 
Apart from pre-college characteristics discussed it is recommended that the college experience as well as post-college measures to be taken into consideration too. For example academic achievement should be insisted among students' loans borrower, which is they must be insisted to be serious in their studies so that they can attain higher grades as measured by GPA which results into less default rate. Financial support is also recommended to be insisted by provision of loans to students basing on criteria which show the financial support among applicants example the presence of collateral securities as a pre requisite for loans provision which will help out the recovery of already issued fund in case of any failure of the students to repay back. Dropouts should be discouraged among students to enable successful completion of students among students' loans borrowers hence discourage default rate among them.

Post college measures including things like highest degree attained, income and marital status of the borrowers should also be considered, even though these factors have been proved to be uncontrollable, as they just happen to a students' loans borrowers after they have already given students' loan, i.e., they happen after college, it is assumed that the higher the degree attained the less the default rate, married students' borrowers with few number of dependants are expected not to defaults more compared to single, divorced or separated, also the higher the income of the students' loans borrowers the lower the default rate and vice versa. Other reasons for defaulting could be (1) Unemployment (2) working but having insufficient funds (3) repaying of some other important loans are also recommended to be looked at.

\section{Limitations and Direction for Future Research}

In this study only the pre-college measures termed as background characteristics were considered as the factors influencing default rate in students' loans, these factors includes age, gender and attitudes. However, some literatures revealed college experience and post-college measures as other factors affecting default rates. Therefore future studies should include the College experience such as academic achievement, financial support and degree completion as well as post-college measures including highest degree attained, income and marital status of a borrower.

This study focused on only Universities/colleges located at Dar es salaam region in Tanzania, leaving other regions with Universities/colleges unexplained. Currently Tanzania has 11 regions with 51 universities/colleges while only 5 universities/colleges has been focused in this paper, therefore future studies should expand to cover more universities/colleges in other regions to make the results more diverse to be applicable to other countries.

Expansion of future studies to factors other than the ones discussed in this study is requires, this study investigated the age, gender and attitude among students' loans beneficiaries as the only factors influencing default rate. These factors explains only $89.7 \%$ of the variance in students' loans default rate, the rest $10.3 \%$ remain unexplained by the model. Although $\mathrm{R}^{2}$ of $89.7 \%$ represents a strong predictive strength, there is a need for future studies to search for additional variables that can improve the predictive ability to predict the students' loans default rate more accurately, factors such as income of students' loans borrowers should be included.

The studies presented in various literatures under the study are based on different data sets. For example many of recent studies analyses data from one university or college such as studies done by Herr and Burt (2005) was on predicting student loan default for the University of Texas only which provide a limited results obtained from a sample with almost the same characteristics.

The amount of researches presented in this study is limited as many of the studies were done in developed countries and a little studies has been made in developing countries therefore in future studies researchers should be encouraged to put more emphasis on students' loans and default rates in developing countries like Tanzania.

\section{Acknowledgement}

My special thanks should go to Prof Chen Yan my supervisor, for constructive comments which shaped this study, I would like also to thank Mr. Michael Felix, and Mr. Cosmas Mwaisobwa my co workers at higher education students' loans board in Tanzania for their material contribution and encouragement. My fellow students, Ms. Upendo Kadikos of Dalian Maritime University, Mr. Joshua Mwakujonga and Mr. Abdul Mussa, of Dongbei University of finance and economics for support and proofreading my manuscript. Also I feel obliged to Mr. Peter Nyahende an MBA student at University of Dar es salaam in Tanzania and Mr. Charles Bogohe who were my research assistants during data collection for their endless support in developing this article. Lastly special thanks should go to students from UDSM, IFM, TUDARCO, CBE and DUCE for providing me with valuable information by filling questionnaires given to them.

\section{References}

Ajzen, I., \& Fishbein, M. (2010). Predicting ad changing behaviour: The reasoned action approach. New York, 
NY: Psychology press.

Barone, S. (2006). Multivariate analysis of student loan defaulters at Prairie view A\&M University. Round Rock, TX: Texas Guaranteed student loan Corporation.

Barr, N. (2009). Financing higher education lessons from economic theory and reform in England. A special issue of Higher education in Europe, 34(2), 201-210. http://dx.doi.org/10.1080/03797720902867419

Barr, N., \& Crawford, I. (2005). Financing education: Answers from the UK. London and New York, NY: Routledge. http://dx.doi.org/10.4324/9780203321515

Baum, S., \& O'Malley, M. (2003). College on credit: How borrowers perceive their education debts. Journal of student financial aid, 33(3), 7-19.

Becker, G. S. (1965). A theoretical and empirical analysis with special reference to education (3rd ed.). Chicago and London: The University of Chicago press.

Callender, C. (2003). Student financial support in higher education: Access and Exclusion. In M. Tight (Ed.), International perspectives on higher education research: Access and Exclusion. Vol 2. CPI Antony Rowe: Eastbourne. http://dx.doi.org/10.1016/S1479-3628(03)80008-4

Carnoy, M. (2006). Higher education and economic development: India, China, and the $21^{\text {st }}$ Century, SCID Working paper No. 297. Stanford Centre for International Development. Retrieved from http://www.stanford.edu/group/siepr/cgi-bin/siepr/?q=system/files/shared/pubs/papers/pdf/SCID297.pdf

Chapman, B. (2006). Income Contingent Loans as Public Policy. Occasional Paper 2/2006, Policy Paper 5, the Academy of the Social Sciences in Australia Canberra. Retrieved from http://www.assa.edu.au/publications/occasional/2006_No2_Income_contingent_loans.pdf

Chapman, B. (2008). Income related student loans: Concepts, International reforms and administrative challenges. In P. Teixeira, D. B. Johnstone, M. J. Rosa, \& H. Vossensteyn (Eds.), Cost-sharing and accessibility in higher education: A Fairer Deal? Dordrecht: Springer.

Choy, S. P., \& Li, X. (2006). Dealing with debt: 1992-93 bachelor's degree recipients 10 years later (NCES 2006-156). Washington, DC: US Department of education, national center for education statistics.

Christman, D. E. (2000). Multiple realities: Characteristics of loan defaulters at a two-year public institution. Community college review, 27(4), 16-32. http://dx.doi.org/10.1177/009155210002700402

Cronbach, L., \& Richard, J. (2004). My Current Thoughts on Coefficient Alpha and Successor Procedures. $\begin{array}{llll}\text { Educational and Pychological } & \text { Measurement, }\end{array}$ http://dx.doi.org/10.1177/0013164404266386

David, A. F. (2009). Statistical Models: Theory and Practice. New York, NY: Cambridge University Press.

Durbin, J., \& Watson, G. (1951). Testing for Serial Correlation in Least Squares Regression, II. Biometrika, 38, 159-179. http://dx.doi.org/10.1093/biomet/38.1-2.159

Eicher, J. C., \& Chevaillier, T. (2002a). Rethinking the financing of post-compulsory education. Higher education in Europe, 27(1)-(2), 69-88. http://dx.doi.org/10.1080/0379772022000003233

Eicher, J. C., \& Chevaillier, T. (2002b). Higher education funding: A Decade of Changes. Higher education in Europe, 27(1)-(2), 89-99. http://dx.doi.org/10.1080/0379772022000003242

Fagerlind, I., \& Saha, L. J. (1989). Education and National Development. A Comparative Perspective (2nd ed.). Oxford: Pergamon press.

Fishbein, M., \& Ajzen, I. (1980). Understanding attitudes and predicting social behaviour. Englewood cliffs, NJ: Prentice-Hall.

Flint, T. (1997). Predicting student loan defaults. The Journal of Higher Education, 68, 322-354. http://dx.doi.org/10.2307/2960044

Harrast, S. A. (2004). Undergraduate borrowing: A study of debtor students and their ability to retire undergraduate loans. Journal of Student Financial Aid, 36(1), 34-52.

Herr, E., \& Burt, L. (2005). Predicting student loan default for the University of Texas at Austin. Journal of Student Financial Aid, 35(2), 27-49.

Higher Education Students' Loans Board. (2004). Act number 9 of 2004 CAP 178. Dar es salaam: Higher Education Students Loans Board. 
Higher Education Students' Loans Board. (2009). Cummulative Loan Repayment Report up to 30th November, 2009. Dar es salaam: Higher Education Students' Loans Board.

Higher Education Students' Loans Board. (2012). The HESLB general notice of February and August, 2012. Dar es Salaam: Higher Education Students' Loans Board.

Higher Education Students' Loans Board. (2013). Loan repayment and recovery report for the second quarter of year 2012/2013 ending Dcemeber, 2012. Dar es salaam: Higher Education Students Loans Board.

Hofstede, G., \& Michael M. (2010). Cultures and Organization: Software of the mind (3rd ed.). New York, NY: McGraw-Hill.

Hossler, D., Gross, J., Osman, C., \& Hillman, C. (2008). A review of the literature: What matters to student loan default. Retrieved from http://www.nasfaa.org/workArea/linkit.aspx?LinkIdentifier=id

Hsu, C. (2008). Nevada's rate of default on college loans among highest in the nation. The Las Vegas Sun (pp. $1-4)$.

Ishengoma, J. M. (2004a). Cost sharing and Participation in Higher Education in Sub-Saharan Africa: The case of Tanzania (Doctoral dissertation). State University of New York, NY at Buffalo.

Jackson, R. (2002). The national student financial aid scheme of South Africa (NSFAS): How and why it works. Welsh Journal of Education Special issue International Issues, 11(1), 82-94.

Johnstone, B. (2006). Financing Higher Education: Cost-Sharing in International Perspective. Massachusetts: Center for International Higher Education Lynch School of Education, Boston College.

Johstone, D. B. (2009). An international perspective of the financial fragility of Higher education institutions and systems, Leading stressed colleges and Universities to excellence (pp. 31-48). Baltimore: The Johns Hopkins University press.

Kesterman, F. (2003). The federal student loan programs need better metrics and default aversion. Journal of Student Financial Aid, 33(2), 43-49.

Kesterman, F. (2006). Student borrowing in America: Metrics, demographics, default aversion strategies. Journal of Student Financial Aid, 36(1), 34-52.

Kinsler, J., \& Pavan, R. (2011). Family income and higher education choices: The importance of accounting for college quality. Journal of human capital, 5(4). http://dx.doi.org/10.1086/663649

Knapp, L. G., \& Terry, G. S. (1992). An analysis of the probability of default on federally guarantees student loans. The review of economics and statistics, 74(3), 404-411. http://dx.doi.org/10.2307/2109484

Lochner, L. J., \& Monge-Naranjo, A. (2004). Education and default incentives with government student loan programs. Working paper, 1-32. Retrieved from http://www.pitt.edu/ ripoll/events/monge1.pdf

Lochner, L. J., \& Monge-Naranjo, A. (2008). The nature of credit constraints and human capital. American economic review, 101, 2487-2529. http://dx.doi.org/10.1257/aer.101.6.2487

Macmillan, P. (2006). Higher Education in the World, The Financing of Universities (1st ed.). Great Britain: William cloves.

Marcucci, P., \& Johnstone, D. B. (2007). Tuition fee policies in a comparative perspective; Theoretical and Political Rationales. Journal of Higher education policy and Management, 29(1), 25-40. http://dx.doi.org/10.1080/13600800600980015

McMillion, R. (2004). Student loan default literature review. Round Rock, TX: Texas Guaranteed Student Loan Corporation.

Migali, G. (2006). Funding higher education and wage uncertainity: Income contingent loan versus Mortgage Loan. Warwick Economics Research Paper Series N. 740. Retrieved from http://www.sciencedirect.com/science/article/pii/S0272775712000696

Mkinga. (2012). Around 80,000 to face court over Tshs 103 billion varsity loans. Retrieved from http://www.thecitizen.co.tz/news/4-national-news/20004-80,000-to-face-court-ocer-Tshs103billion-varsity-1 oans.html

Monteverde, K. (2000). Managing student loan default risk: Evidence from a privately guaranteed portifolio. Research in higher education, 41(3), 331-352. http://dx.doi.org/10.1023/A:1007090811011

Mora, J., \& Vila, L. (2003). The economics of higher education. In R. Begg (Ed.), The Dialogue between higher 
education research and practice (pp. 121-134). Kluwer Academic Publishers. http://dx.doi.org/10.1007/978-0-306-48368-4_10

Mower, L. (2007). Student loans: Default rate high in Nevada. Las Vegas Review-Journal, 1-3.

Nyahende, V. R. (2013). The success of students' loans in financing higher education in Tanzania. The Journal of Higher Education studies, 3(3), 47-61. http://dx.doi.org/10.5539/hes.v3n3p47

Olaniyan, D. A., \& Okemakinde, T. (2008). Human capital theory: Implications for educational development. European Journal of Scientific Research. Euro Journals Publishing, 24(2), 157-162.

Palacios, M. (2002). Human capital contracts, Equity-like Instruments for financing higher education. Policy analysis, 462.

Podgursky, M., Ehlert, M., Monroe, R., Watson, D., \& Wittstruck, J. (2002). Student loan defaults and enrollment persistence. Journal of Student Financial Aid, 32(3), 27-42.

Psacharopoulos, G., \& Patrinos, H. A. (2002). Returns to investment in education: A further update. World Bank policy research working paper 2881. Retrieved from http://siteresources.worldbank.org/EDUCATION/Resources/278200-1099079877269/547664-10990799344 75/547667-1135281504040/Returns_Investment_Edu.pdf

Robbins, S. P. (2009). Organizational behaviour; global and Southern African perspectives. Cape Town, Pearson: Education South Africa.

Saunders, M., Lewis, P., \& Thornhill, A. (2007). Research methods for Business students (4th ed.). New York, NY: Prentice Hall.

Shen, H., \& Ziderman, A. (2008). Students loans repayment and Recovery: International Comparisons. Department of Economics, Bar Ilan University, Tel Aviv.

Snooks, G. (2008). A general theory of complex living systems: Exploring the demand side of dynamics. Complexity, 13, 12-20. http://dx.doi.org/10.1002/cplx.20225

Steiner, M., \& Teszler, N. (2003). The characteristics associated with student loan default at Texas A\&M University. Texas Guaranteed: Texas A\&M University.

United Republic of Tanzania. (2005). Review of Financial Sustainability in Financing Higher Education in Tanzania. Dar es Salaam: Ministry of Science, Technology and Higher Education (MSTHE).

United Republic of Tanzania. (2007). Basic Statistics on Higher Education 2002/2003-2006/2007 MSTHE. Dar es Salaam: Government Printing Press.

Volkwein, J. F., \& Szelest, B. P. (1995). Individual and campus characteristics associated with student loan default. Research in higher education, 36(1), 41-72. http://dx.doi.org/10.1007/BF02207766

Woo, J. H. (2000b). Factors affecting the probability of default: Student loans in California. Journal of Student Financial Aid, 32(2), 5-23.

Woo, J. H. (2002a). Clearing accounts: The causes of students loan default. Rancho Cordova, CA: EdFund.

Woodhall, M. (2002a). Student loans: Potential, Problems and Lessons from International Experience Institute of Education. University of London: Institute of Education.

Woodhall, M. (2002b). Paying for learning: The debate on student fees, grants and loans in international perspective. Special International Issue of the Welsh Journal of Education, 11(1).

Woodhall, M. (2007). Funding Higher Education; The contribution of Economic Thinking to Debate and policy development. Washington, DC: World Bank.

World Bank. (1986). Financing Education in Developing Countries: An Exploration of Policy Options. Washington DC: World Bank.

World Bank. (1994). Higher Education: The Lessons of Experience. Washington, DC: World Bank.

World Bank. (2008a). Accelerating catch-up: Tertiary Education for Growth in Sub-Saharan Africa. Washington, DC: World Bank.

World Bank. (2008b). Project Appraisal Document; Science and Technology Higher Education Program, Tanzania. Washington, DC: World Bank.

World Bank. (2009). World development indicators. Washington, DC: World Bank. 


\section{Appendices}

\section{Appendix I}

\section{QUESTIONNAIRES}

The main aim of this questionnaire is to get information on the Influence of students' loans borrowers' characteristics on default rate in Tanzania. The questionnaire specifically covers students who are loans beneficieries in the selected higher learning institutions. The results of this research will be used solely for academic purposes. You are requested to complete this questionnaire promptly as directed to enable timely accomplishment of the study, kindly note that the information provided will be treated as a confidential and it will in no way would it be conveyed to any other person.

SECTION A: General Information, Please fill in the blank spaces provided.
(1) Age 18-24 yrs [ ] 25-30 yrs [ ] 31-35 yrs [ ] 36-40 yrs [ ] 41 and above [ ]

(2) Gender Male [ ] Female [ ]

(3) Professional Business Management [ ] General Science (Specify) [ ]

Law [ ]
Erts [ $]$

(4) District

(5) In which University/College do you belong among the ones enlisted? (Please tick)

\begin{tabular}{|l|l|l|l|l|}
\hline UDSM & DUCE & TUDARCO & IFM & CBE \\
\hline & & & & \\
\hline
\end{tabular}

For Section B, C, D and E please circle correctly

SECTION B: Student loans borrowers' age (A)

$1=18-24, \quad 2=25-30, \quad 3=31-35, \quad 4=36-40, \quad 5=41 \&$ Above

(1) Am willing to repay the loan after completion of my studies.
Young
1
2
34
5
Adult

(2) I Have started repaying back the students' loans.
Young 1
2
34
5
Adult

(3) I know that the loan is meant to be revolving so that others can also benefit from it.
Young
1
2
34
5
Adult

(4) Am aware that I will have to repay the loan upon completion of your studies.
Young
1
23
4
5
Adult

(5) I always follow the procedures to repay back the students loan.
Young
1
23

4 5
Adult

SECTION C: Students loans borrowers' gender (B)

1= Male 2=Female

(1) Am willing to repay the loan after completion of my studies.
Male
1
2 Female

(2) I Have started repaying back the students' loans.
Male
1
2 Female

(3) I am aware that the loan is meant to be revolving so that others can also benefit from it.
Male
2
Female

1


(4) Am aware that I will have to repay the loan upon completion of your studies.

$$
\text { Male } \quad 1 \quad 2 \quad \text { Female }
$$

(5) I always follow the procedures to repay back the students loan.
Male
1
2
Female

SECTION D: Students loans borrowers' attitude (C)

1=Fair, 2=Average, 3=Good, 4=Very good, 5=Excellent

What describes you to show ability and willingness to repay the loans?

(1) I always declare my debts.
Not at all 1
2
34
5
To a great extent

(2) Given the precise information from the relevant authority I prefer to pay my debt timely.
Not at all 1
23
4
5
To a great extent

(3) If there was a need to maintain a good credit history, I would declare my debts timely.
Not at all 1
23
4
5
To a great extent

(4) I always follow the procedures to repay back the students loan.
Not at all 1
23
4
5
To a great extent

(5) Am willing to repay the loan after completion of my studies.
Not at all 1
23
4
5
To a great extent

\section{SECTION E: Students loan default rate}

\section{1=Fair, $\quad 2$ =Average, $\quad 3=$ =Good, $\quad$ 4=Very good, $\quad 5=$ =xcellent}

(1) HESLB is employing enough strategies to ensure that previous loans are recovered to reduce default rate.
Not at all 1
23
45
To a great extent

(2) HESLB is reducing default rate by having a committed management in loan recovery.
Not at all 1
23
$4 \quad 5$
To a great extent

(3) HESLB is using repaid amount to covers administration costs without depending on government subsidies.
Not at all 1
23
45
To a great extent

(4) Mechanism used by HESLB to identify the loan beneficiaries, so as to recover the already given out funds are effective.
Not at all 1
23
45
To a great extent

(5) HESLB is employing enough efforts to recover loans granted to beneficiaries since 1994.
Not at all 1
23
4
5
To a great extent

(6) HESLB policies and procedures for collecting the already issued funds are effective
Not at all 1
23
$4 \quad 5$
To a great extent

\section{THANK YOU VERY MUCH FOR YOUR CO-OPERATION}




\section{Appendix II}

Table 6. Frequency distribution of respondents' AGE

\begin{tabular}{llllll}
\hline & & Frequency & Percent & Valid Percent & $\begin{array}{l}\text { Cumulative } \\
\text { Percent }\end{array}$ \\
\hline \multirow{4}{*}{ Valid } & 18-24YRS & 95 & 63.3 & 63.3 & 63.3 \\
& $25-30$ YRS & 22 & 14.7 & 14.7 & 78.0 \\
& $31-35$ & 18 & 12.0 & 12.0 & 90.0 \\
& $36-40$ & 10 & 6.7 & 6.7 & 96.7 \\
& 41 AND ABOVE & 5 & 3.3 & 3.3 & 100.0 \\
& Total & 150 & 100.0 & 100.0 & \\
\hline
\end{tabular}

Source: Field data (2012)

Table 7. Frequency distribution of respondents' GENDER

\begin{tabular}{llllll}
\hline & & Frequency & Percent & Valid Percent & $\begin{array}{l}\text { Cumulative } \\
\text { Percent }\end{array}$ \\
\hline \multirow{4}{*}{ Valid } & MALE & 98 & 65.3 & 65.3 & 65.3 \\
& FEMALE & 52 & 34.7 & 34.7 & 100.0 \\
& Total & 150 & 100.0 & 100.0 & \\
\hline
\end{tabular}

Source: Field data (2012)

Table 8. Frequency distribution of respondents by university/college

\begin{tabular}{llllll}
\hline & & Frequency & Percent & Valid Percent & $\begin{array}{l}\text { Cumulative } \\
\text { Percent }\end{array}$ \\
\hline \multirow{6}{*}{ Valid } & UDSM & 50 & 33.33 & 33.33 & 33.33 \\
& DUCE & 25 & 16.67 & 16.67 & 50 \\
& CBE & 25 & 16.67 & 16.67 & 66.67 \\
& TUDARCO & 20 & 13.33 & 13.33 & 80 \\
& IFM & 30 & 20 & 20 & 100.0 \\
& Total & 150 & 100.0 & 100.0 & \\
\hline
\end{tabular}


Table 9. Reliability of constructs

\begin{tabular}{|c|c|c|c|c|}
\hline Constructs & Items & $\begin{array}{l}\text { Number } \\
\text { of items }\end{array}$ & $\begin{array}{l}\text { Cronbach's } \\
(>0.7)\end{array}$ & Alpha \\
\hline Age factors & $\begin{array}{l}\text {-To repay the loan } \\
\text { - Started repay } \\
\text {-Revolving the default rate } \\
\text {-How to repay loans } \\
\text {-Follow procedures }\end{array}$ & 5 & 0.91 & \\
\hline Gender factors & $\begin{array}{l}\text { - To repay the loan } \\
\text {-Started repay } \\
\text {-Revolving the default rate } \\
\text {-How to repay loans } \\
\text {-Follow procedures }\end{array}$ & 5 & 0.82 & \\
\hline Attitude factors & $\begin{array}{l}\text {-Declare my debts } \\
\text {-Pay debts timely } \\
\text {-To maintain a credit history } \\
\text {-Follow the procedures } \\
\text {-To repay the loan }\end{array}$ & 5 & 0.84 & \\
\hline $\begin{array}{l}\text { Students' Loan default } \\
\text { rate }\end{array}$ & $\begin{array}{l}\text {-Recovering default rate } \\
\text {-Management commitment } \\
\text {-Covers administrative costs } \\
\text {-Maintenance of capital value } \\
\text {-Sufficient funds to students } \\
\text {-Availability of fund to the needy }\end{array}$ & 6 & 0.87 & \\
\hline
\end{tabular}

Source: Filed data (2012) 


\section{Appendix III}

HESLB-SLF 2

\section{HIGHER EDUCATION STUDENTS' LOANS BOARD}

Tirdo Complex, Kimweri Road, Dar es Salaam, Tanzania

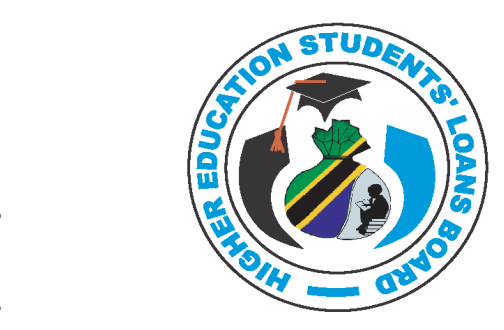

Tel: $\quad$ (General) $+255 \quad 22$ +255 $22 \quad$ 2669039; E-mail:

Website: www.heslb.go.tz

Msasani; P.O.Box 76068,

\section{STUDENT'S LOAN AGREEMENT FORM}

(MKATABA WA MKOPO KWA MWANAFUNZI)

Form IV

Index No

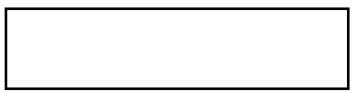

Course of Study
Completion Year

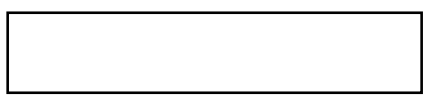

Registration No

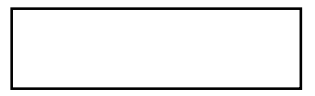

Institution of Study

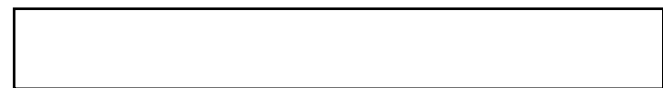

Admission Year
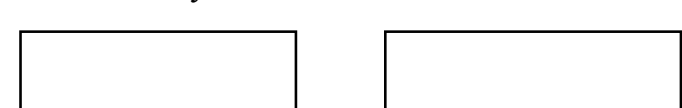

\subsection{Parties to this agreement}

This agreement is being entered into between Higher Education Students' Loans Board of the above appearing address herein referred to as the "Board" and (Mkataba huu ni kati ya Bodi ya Mkopo ya Wanafunzi wa Elimu ya Juu hapa ikijulikana kama “Bodi” (na)

\begin{tabular}{|l|l|}
\hline $\begin{array}{l}\text { Surname } \\
\text { (Jina la Ukoo) }\end{array}$ & \\
\hline $\begin{array}{l}\text { First Name } \\
\text { (Jina la Kwanza) }\end{array}$ & \\
\hline $\begin{array}{l}\text { Other Names } \\
\text { (Majina Mengine) }\end{array}$ & \\
\hline Bank Name & \\
(Jina la Benki) & \\
\hline $\begin{array}{l}\text { Bank Branch } \\
\text { (Tawi la Benki) }\end{array}$ \\
\hline $\begin{array}{l}\text { Account Number } \\
\text { Namba ya }\end{array}$ \\
\hline
\end{tabular}

\begin{tabular}{|lr|}
\hline Applicants & \\
Passport & size \\
Colour & Photo \\
(Picha & ya \\
Mwombaji & \\
pasipoti ya rangi)
\end{tabular}

Who in this agreement shall be referred to as the "Student" (ambapo katika mkataba huu atajulikana kama "mwanafunzi”) 


\subsection{Terms and Conditions: (Kanuni na Masharti)}

2.1. The students loan agreement forms shall be signed for every fresh loans granted by the Board every academic year but the cumulative amount granted every year shall form part of this agreement. (Fomu za mkataba wa mkopo huu zitasainiwa kila mwaka kwa kiasi cha nyongeza au mafungu ya mkopo ambayo kwapamoja yatakuwa sehemu ya mkataba huu).

2.2. The Contractual amount, consideration of which shall be Tanzanian shilling one thousand only, shall be that amount disbursed by the Board to Bank account of the student and; the amount paid directly to the student through institution of study and; the amount paid by the Board to the bank account of the institution where the student is admitted for studies for the costs related to the student's pursuance of studies and; any subsequent amount as shall be disbursed by the Board. (Kiasi cha mkopo atakachokopeshwa mwanafunzi kwa mujibu wa mkataba huu, kitakuwa ni zile fedha zitakazopelekwa moja kwa moja kwenye akaunti ya Benki ya mwanafunzi na kile kiasi kitakacholipwa taslimu moja kwa moja kwa mwanafunzi kupitia chuo anachosoma, na fedha ambazo zitakazolipwa moja kwa moja kwenye akaunti ya chuo anachosoma mwanafunzi na zile ambazo zitaendelea kulipwa ama kwa mwanafunzi ama kwa chuo zikihusishwa na gharama za masomo ya mwanafunzi).

2.3. The student shall, through the institution of study, update the Board on the academic status of the student immediately upon completion of each academic year and within such reasonable time to allow the Board to process the student's subsequent loan disbursement. (Ni jukumu la mwanafunzi kuijulisha Bodi kuhusu kuendelea kwake na mwaka mpya wa masomo au vinginevyo, kila baada ya mwaka wa masomo kumalizika kupitia chuo anachosoma mwanafunzi, na ndani ya muda wa kutosha kuiwezesha Bodi kuandaa malipo ya mkopo kwa mwaka wa masomo utakaofuata).

2.4. Loan money for tuition fees, special faculty requirements and other institutional costs shall be paid directly to the respective bank account of the institution of study. (Mkopo kwa ajili ya ada ya mafunzo na mahitaji maalumu ya kitivo zitalipwa moja kwa moja katika asasi ya mafunzo inayohusika).

\section{Copyrights}

Copyright for this article is retained by the author(s), with first publication rights granted to the journal.

This is an open-access article distributed under the terms and conditions of the Creative Commons Attribution license (http://creativecommons.org/licenses/by/3.0/). 